\title{
Юлія Нікішенко,
}

кандидат історичних наук, доцент,

Національний університет

«Києво-Могилянська академія»,

Київ, Україна

julianikish@gmail.com

http://orcid.org/0000-0002-8649-93

\section{МАТЕРІАЛЬНА КУЛЬТУРА ТА ОКРЕМІ ІІЇ СКЛАДОВІ В ПРАЦЯХ ЕТНОЛОГІВ ТА КУЛЬТУРОЛОГІВ}

Останнім часом поняття «матеріальна культура» сприймається дещо неоднозначно, але на термінологічному рівні це поняття існує і продовжує широко використовуватись як етнологами, так і культурологами. Ми пропонуємо проаналізувати визначення поняття «матеріальна культура», яке було сформульовані в етнології та культурології, аби зрозуміти - який зміст вкладали в нього дані гуманітарні напрями.

Ключові слова: річ, матеріальна культура, етнологія, культурологія.

В сучасній гуманітарній галузі поняття "культура" відноситься до ряду фундаментальних. Над проблематикою структури та характеристик складових частин культури, в тому числі й етнічної, працювали в різні часи такі відомі теоретики етносу та культурологи, як Ю. Бромлей (2009), С. Арутюнов (1989), С. Маркарян (1969) та інші, із західних дослідників виділимо, зокрема, Е. Тайлора (1989), О. Шпенглера (1993). Погляд на культуру, як особливу сферу суспільного та особистого життя характерний для сучасної західної філософії. її визначальними чинниками вважають цінності (М. Вебер, 1990), сталі структури мови та мислення (структуралізм), символічної форми (К. Юнг), первісні ідеї різного типу (О. Шпенглер, 1993).

У загальному розумінні культуру визначають як таку форму життєдіяльності людей, яка, перш за все, фіксує відмінність біологічних, природних форм життя від діяльності людини згідно з ії потребами, інтересами, уподобаннями і представлена продуктами матеріального та духовного виробництва, людськими взаєминами, ставленням людини до себе самої. Якісним виміром культури $є$ своєрідність їі історичних, національних форм, а також форм суспільної свідомості та діяльності індивідів, соціальних і етнічних групу їх предметно-практичному та духовному опануванні об’єктивної дійсності. В етнології можна зустріти таке визначення: «культура - позабіологічно вироблений та передаваний спосіб людської діяльності, адаптивний механізм, що полегшує людині життя у світі» (Садохин, 2006, с. 280). Загалом важко назвати інше слово, яке б мало стільки смислових відтінків. 
В цілому культура, як об'єкт дослідження, є настільки невичерпною, що попри тривалу традицію іï вивчення як етнологами так і культурологами залишається відкритою низка питань, що потребують поглибленого дослідження. У тому числі це стосується їі морфології і, зокрема, проблеми виокремлення матеріальної культури, як частини структури культури в цілому. Сюди ж можна віднести і питання щодо окремих складових матеріальної культури в контексті їх приналежності до предметного світу. Сам термін «матеріальна культура» застосовується і в етнології і в культурології, але певних узагальнених підходів до його розгляду поки що не вироблено.

Ми пропонуємо зосередитись саме на цій частині проблеми і детальніше проаналізувати той контекст, який науковці - етнологи та культурологи - вкладають у поняття «матеріальна культура» і які його складники виокремлюють. Дане питання за своєю тематикою та обсягом $€$ досить об'ємним і не може бути розкритим навіть частково в межах одного дослідження, тому ми пропонуємо зосередитися на тих визначеннях матеріальної культури, що даються передовсім вітчизняними авторами, а також розглянути, на яких компонентах матеріальної культури сходяться точки зору представників різних галузей гуманітарного знання. Для цього перш за все планується проаналізувати літературу теоретичного характеру, присвячену дослідженням в царині культурології та етнології, де саме і розглядаються поняття, що нас цікавлять. У тому числі як джерела були обрані також і підручники Н. Бесарабової «Культурологія» (2010), А. Бістрової «Світ культури» (2002), П. Гуревич «Культурологія» (1996), А. Пономарьова «Етнічність та етнічна історія України» (1996) та ін., оскільки їх автори, аналізуючи поняття «культура» в цілому, звертаються також до проблем її морфології та до виокремлення поняття «матеріальна культура» і її складників.

Окремо варто зазначити, що саме питання поділу культури на матеріальну і духовну $є$ досить дискусійним і існують різні точки зору з приводу того, наскільки це взагалі можна робити (Каган, с.179). Думку про те, що складність внутрішньої структури культури як цілісного феномена обумовлені складністю та багатоманітністю людської життєдіяльності та творчості і про те, що цей поділ умовний, зустрічаємо в різних джерелах (Бесарабова, 2010, с.15-16; Костина, 2010, с. 23; Культурологія, 2005, с. 26; Лекції з історії світової та вітчизняної культури, 2005, с. 13; Философский словарь, 2001, с. 272).

Але попри те, що подібна думка щодо суперечливості та недоцільності розділення культури на матеріальну та духовну зустрічається у багатьох авторів, дана термінологія існує і продовжує застосовуватись, а тому $€$ сенс простежити і традиції іï застосування і контекст, який у неї вкладається.

Зокрема, зазначається, що сучасна цивілізація визначила досить стійку тенденцію в розвитку культури - інтеграцію їі складових частин. 
Ю. В. Бромлей вважає, що подібний поділ базується на тому, що у якості критеріїв визначення внутрішньої структури культури значно частіше, ніж діяльність, виступають форми ії «опредмечування» (Бромлей, 2009, с. 107). Ми в нашому дослідженні не будемо торкатися цієї сторони проблеми, щоб не розпорошувати увагу, лише визнаємо, що такий поділ поки що існує, хоча й досить умовний, а об'єктом даної роботи буде саме матеріальна культура, як складова культури в цілому.

Поняття «матеріальна культура» в етнології виникло, як вважається, y XIXCT., коли почалося її більш активне вивчення тогочасними дослідниками етнічної культури. Але на теоретичному рівні етнологи їі досліджують не настільки активно, щоб сформулювати розширений понятійний апарат, віддаючи перевагу практичній роботі. Зазвичай вони застосовують це поняття без залучення розширених визначень, виносячи його у якості позначення всього предметного світу етнічної культури (Истс, 1991, с. 75-78; Культура і побут населення України, 1993, с. 59-147; Пономарьов, 1996, с. 220-264). У даному випадку можна зазначити, що використання поняття «матеріальна культура» має скоріше прикладний характер, ніж теоретичний, хоча автори і вказують на те, які компоненти вони до нього включають (Тайлор, 1989, с. 220-221). Натомість можемо бачити, що теоретична сторона цієї проблеми набагато краще розроблена культурологами, які розробили достатньо розгалужену та глибоку систему визначень поняття «матеріальна культура». Тобто, етнологи, застосовуючи це поняття, не завжди переймалися його теоретичним обґрунтуванням, натомість культурологи, для яких матеріальна культура не $є$ безпосереднім об'єктом дослідження, створили його визначення та розмістили в контексті морфологічної структури культури в цілому.

Якщо звернутися до загальних визначень поняття «матеріальна культура», то побачимо, що загалом вважається, що матеріальна культура виникає на ґрунті матеріальної діяльності та характеризує цю діяльність з погляду їі впливу на розвиток людини. Сюди входять: культура праці та матеріального виробництва; культура побуту; культура топосу, тобто місця проживання (помешкання, будинки, села, міста); культура ставлення до власного тіла та ін. (Лекції з історії світової та вітчизняної культури, 2005, с. 13). Можливо, саме через це матеріальну культуру, розуміють як певне «опредмечення» слідів духовного світу та поведінки людей і відносять таке розуміння до археологічного (Кармин, 2003, с. 10-11). Подібну думку можна зустріти і у М. С. Кагана (1996, с. 180), який пише, що у нас із 1920-х рр. цим поняттям стали визначати предмет археології і ототожнювати ії зі світом речей.

Розглянемо визначення матеріальної культури детальніше, зокрема, звернемось до того - які компоненти включають у матеріальну культуру етнологи та культурологи. Ми вже наводили одне із загальнихії визначень, розглянемо деякі інші. Приміром, матеріальною культурою вважають житло, засоби комунікації - все те, що зрештою отримало назву штучного 
середовища мешкання людини і є процесом та результатом матеріальної діяльності людини. Інакше кажучи, під матеріальною культурою розуміють сукупність матеріальних елементів. Можна бачити і більш розширене розуміння матеріальної культури, куди включають культуру праці та матеріального виробництва, культуру побуту, культуру топосу, тобто, місця проживання (житла, будинку, села, міста), культуру ставлення до власного тіла, фізичну культуру (Столяренко, 2010, с. 18).

Також визначення матеріальної культури обумовлюють властивостями природних об'єктів, котрі використовуються людиною у якості сировини при створенні матеріальних предметів, продуктів, засобів існування (Касьянов, 2010, с. 20). Матеріальну культуру визначають як матеріальні продукти, результати та процеси людської діяльності, те, в чому опредмечується духовна культура і вбачають у ній результат виходу людини за межі природи, інстинкту, результат створення того, що не створено самою природою (Штомпель, 2001, с. 90).

Етнологи у найбільш широкому сенсі розуміють матеріальну культуру як сукупність всіх створених людською працею матеріальних предметів конкретного суспільства у їх функціональному взаємозв'язку. У більш вузькому, але традиційно частіше вживаному сенсі - як матеріальні форми культури, спрямовані на безпосереднє задоволення вітальних потреб, тобто, на життєзабезпечення. Також може бути й інший підхід - коли упоняття «матеріальна культура» включають практично повністю культуру виробництва та життєзабезпечення (Свод этнографических понятий и терминов, 1989, с. 5-6). Як і будь-яка інша підсистема культури, матеріальна культура являє собою механізм адаптації суспільства до умов природного та соціального середовища його існування. Інакше кажучи, в ній знаходять відображення як природно-географічне середовище мешкання, так і рівень його суспільно-економічного розвитку, політична структура, оточення та інші конкретні історичні умови (Свод этнографических понятий и терминов, 1989, с. 6).

Іноді до матеріальної культури відносять процеси, засоби та способи створення та споживання названих продуктів - технологічну грань, а також технічну культуру самих творців та споживачів предметного світу чи його фрагментів - суб'єктну грань. Зазначається, що матеріальна культура має не лише якісно різні грані, але й кількісно різні зрізи. Вона може бути розглянута на різних рівнях: від одиничних предметів, процесів та людей до глобальних цивілізацій.

Якщо говорити про те, які складники виокремлюють дослідники, говорячи про матеріальну культуру, то це засоби матеріального виробництва, енергетичні та сировинні ресурси, технології матеріального виробництва, а також знаряддя праці (від найпростіших форм до новітніх потужних комплексів) та виробничі відносини. До матеріальної культури включають і засоби комунікації, а іноді навіть парки та дороги (Касьянов, 2010, с. 20). М. С. Каган (1996, с. 46) відносить до складників 
матеріальної культури створюваний людьми світ технічних засобів їх впливу на природу та на самих себе - від створення своїх штучних органів, виробничих інструментів, знарядь праці та війни, що компенсують природну фізичну слабкість людини, до винаходу хитромудрих машин, приладів, засобів пересування, зброї та засобів комунікації - від письма та книгодрукування до радіо- та телевізійного зв'язку. Також, на думку автора, до матеріальної культури можна віднести предметне буття всіх закладів, організацій, суспільних інституцій, оскільки вони існують об'єктивно як реальні утворення, створені людьми, але стали від них незалежними, оскільки люди, що функціонують у державних органах, суді, університеті тощо, приходять і йдуть, форми цих організацій та інституцій змінюються, але самі вони - держава, суд, школа - зберігаються, перебувають, існують нібито самі по собі, і в цьому сенсі матеріальні - як форми опредмеченого буття суспільних стосунків.

Тобто, ми бачимо, що на загальному рівні до складників матеріальної культури можна віднести «світ речей, створених або перетворених людиною. До них відносяться нові різновиди рослин, нові породи тварин, виробництво, споживання, побут і сама людина у своїй матеріальній сутності» (Быстрова, 2002, с. 56).

Для теоретиків етносу поняття «матеріальна культура» охоплює не лише матеріально об'єктивовані явища культури у сфері виробництва та споживання, але й пов'язані з ними форми людської діяльності, орієнтації та досвіду (Свод этнографических понятий и терминов, 1989, с. 6). В останньому випадку в матеріальну культуру включається перш за все житло, їжа та одяг, а також начиння, меблі тощо, але не включаються знаряддя праці та транспортні засоби (Свод этнографических понятий и терминов, 1989, с. 5-6). Останнє твердження демонструє певні відмінності між етнологами та культурологами у підході до того - які складові матеріальної культури можна виокремити. Зокрема, це стосується і розуміння того, наскільки значною складовою матеріальної культури можна вважати світ речей як таких.

Про те, що матеріальна культура є сукупністю речей, тобто, штучно створеним людиною світом, говорять різні дослідники. Іноді його також називають «другою природою». I значна частина культурологів серед важливих складників матеріальної культури називає артефакти - фізичні об'єкти, створені руками людини (Кравченко, 2003, с. 15-16). Також артефакти, визначають як продукти та результати людської діяльності, штучно створені людиною предмети та явища. Артефактами феноменами культури - є виготовлені людиною речі, ї̈ думки, винайдені та використані нею засоби та способи дії (Садохин, 2006, с. 9). До кола артефактів належать: матеріальні речі, створені або оброблені людьми (предмети побутового вжитку, одяг, житло, зброя, засоби транспорту і зв'язку тощо); штучно перетворені території (міста, окультурені землі); матеріальні носії ідей та образів (графічні, образотворчі, звукові, 
електронні записи); одомашнені тварини та відселектовані рослини (Шпенглер, 1993, с. 90-91). Тобто, артефакти виступають як продуктивнопредметна грань матеріальної культури.

Отже, можна сказати, що матеріальну культуру співставляють із предметною діяльністю людини, зі світом артефактів та речей. Зокрема, існує точка зору, що «іще одна важливість культурної діяльності полягає в тому, що вона предметна у своїй суті, тобто, спрямована на створення предметів» (Культурология, 2005, с. 25). Тобто, матеріальну культуру в культурології сприймають як культуру, одягнену в річ (Пигалев, 1999, с. 8).

Етнологи також виокремлюють річ, як складову матеріальної культури, однак не виокремлюють їх як самостійний об'єкт дослідження: «Оскільки «речі цікавлять етнографа не самі по собі а в їх відношенні до людини» (Токарев, 1970, с. 3), постільки такі явища як предмети побуту, начиння, їжа, одяг, житло лише формально є вихідними об'єктами дослідження матеріальної культури; по суті зусилля етнографів спрямовані перш за все на вивчення обставин виготовлення предметів побуту та їх функцій...тобто, на пізнання відносин між предметом ідіяльністю людини, ї локальної та етнічної специфіки» (Свод этнографических понятий и терминов, 1989, с. 6). Втім, предметний світ, а, отже, і річ, визнається важливим джерелом, хоча саме поняття «річ», застосовується не завжди, або ж використовуються наближені поняття, приміром, «предметний світ»: «Найважливішими групами джерел для дослідження матеріальної культури є предметні джерела, як поза рамками так і в рамках історичної функціональної сукупності» (Свод этнографических понятий и терминов, 1989, с. 7).

C.A. Токарєв (1970, с. 3), зокрема, писав, що хоча від етнографадослідника вимагається вміння описувати з максимальною точністю і повнотою явища матеріальної культури, описи речей залишаються лише допоміжними прийомами, а не метою наукового етнографічного дослідження. Більше того, він наголошував, що «для нас не настільки важливо знати відношення речі до людини або відношення людини до речі, скільки відношення між людьми з приводу даної речі» (Токарев, 1970, с. 3). Подібне ставлення до речі з боку теоретиків було притаманне етнологам радянської доби, сучасна етнологія потроху розширює коло своїх наукових інтересів, у тому числі й у даному напрямку.

В цілому, як бачимо, і етнологи і культурологи практично одностайно сходяться на тому - як визначати матеріальну культуру в контексті культурологічних та етнокультурних досліджень. Так само ми бачимо подібне ставлення в етнології та культурології до виокремлення певних складників матеріальної культури. Щоправда, перелік цих складників детальніше розписаний у визначеннях поняття «матеріальна культура», які наводяться у культурологічних дослідженнях, натомість етнологи, прямо їх не називаючи, детально аналізують функції, якісний та кількісний склад цих компонентів безпосередньо при дослідженні різних рівнів етнічної 
культури. Інша річ полягає у тому, що можна спостерігати певні відмінності на методологічному рівні та у теоретичному обґрунтуванні й сприйнятті окремих компонентів матеріальної культури в етнології та культурології, але це вже виходить за межі даного дослідження. Загалом, варто констатувати, що питання щодо розуміння та визначення поняття «матеріальна культура» в гуманітарних напрямах залишає широке коло проблем, які потребують уваги дослідників і можуть стати темами для подальших досліджень у цій царині.

\section{СПИСОК ПОСИЛАНЬ}

Арутюнов, С.А. (1989). Народы и культуры: развитие и взаимодействие. Москва: Наука.

Бесарабова, Н.В. (2010). Культурология. Москва: МГИ им. Е.Р. Дашковой.

Бондарчик, В.К., Браим, И.Н., \& Бураковская, Н.И. Полесье: Материальная культура. Киев: Наукова думка, 1988.

Бромлей, Ю., \& Штробах, Г. (1989). Свод этнографических понятий и терминов. Москва: Наука.

Бромлей, Ю.В. (2009). Очерки теории этноса. Москва: Либроком.

Быстрова, А.Н. (2002). Мир культуры: Основы культурологии (2-е изд.). Москва: Издательство Фёдора Конюхова.

Вебер, М. (1990). Избранные сочинения. Москва: Наука.

Гуревич, П.С. (1996). Культурология. Москва: Знание.

Доброхотов, А. Л., \& Калинкин, А.Т. (2010). Культурология. Москва: Форум.

Итс, Р.Ф. (1991). Введение в этнографию. Ленинград: Издательство Ленинградского университета.

Каган, М.С. (1996). Философия культуры. Санкт-Петербург: Петрополис.

Каган, М.С. (2003). Введение в историю мировой культуры. (Кн. 1). СанктПетербург: Петрополис.

Кармин, А.С. (2003). Культурология. Санкт-Петербург: Лань.

Касьянов, Б.Б. (2010). Культурология. Ростов-на-Дону: Феникс.

Кирамова, К.А. (2004). Культурология в вопросах и ответах. Москва: Велби.

Костина, А.В. (2010). Культурология (5-е изд.). Москва: КНОРУС

Кравченко, А.И. (2003). Культурология (4-е изд.) Москва: Академический Проект. Культура і побут населення України (2-ге вид.). (1993). Київ: Либідь.

Маркарян, Э.С. (1969). Очерки теории культуры. Ереван: Издательство АН АССР.

Пигалев, А.И.(1999). Культурология. Волгоград: Издательство Волгоградского государственного университета.

Подольская, Е.А., Иванова, К.А., \& Лихвар, В.Д. (2003). Культурология. Харьков: Золотые страницы.

Пономарьов, А.П. (1996). Етнічність та етнічна історія України. Київ: Либідь.

Садохин, А.П. (2006). Этнология. Москва: Гардарики.

Солонин, Ю.Н. \& Соколов, Е.Г. (Ред.). (2003). Введение в культурологию. СанктПетербург.

Солонин, Ю.Н., \& Каган, М.С. (Ред.). (2005). Культурология. Москва: Высшее образование.

Столяненко, Л.Д., Самыгин, С.И., Илюхина, Л.В., \& Ларькова, Е.П. (2010). Культурология (4-е изд.). Ростов-на-Дону: Феникс. 
Тайлор, Э. (1989). Первобытная культура. Москва: Политиздат.

Токарев, С.А. (1970). К методике этнографического изучения материальной культуры. Советская этнография, 4, 317.

Фролов, И.Т. (2001). Философский словарь. Москва: Республика.

Шпенглер, О. (1993). Гештальт и действительность. В Закат Европы: Очерки морфологии мировой истории. (Т. 1). Москва: Мысль.

Штомпель, Л.А. (2001). Материальная культура. В Г.В. Драч, \& Т.П. Матяш (Ред.). Культурология: Краткий терминологический словарь (с. 90-91). Ростов-наДону: Феникс, 2001.

Яртись, А. \& Мельник, В. (2005). Лекції з історії світової та вітчизняної культури (2-ге вид.). Львів: Світ.

\section{REFERENCES}

Arutyunov, S.A. (1989). Narodyi i kulturyi: razvitie i vzaimodeystvie [Peoples and cultures: development and interaction]. Moscow: Nauka [in Russian].

Besarabova, N.V. (2010). Kulturologiya [Cultural Studies]. Moscow: MGI im. E.R. Dashkovoy [in Russian].

Bondarchik, V.K., Braim, I.N., \& Burakovskaya, N.I. (1988). Polese: Materialnaya kultura [Polesie: Material Culture]. Kyiv: Naukova dumka [in Russian].

Bromley, Yu., \& Shtrobah, G. (1989). Svod etnograficheskih ponyatiy i terminov [Code of ethnographic concepts and terms]. Moscow: Nauka [in Russian].

Bromley, Yu.V. (2009). Ocherki teorii etnosa [Code of ethnographic concepts and terms]. Moscow: Librokom [in Russian].

Byistrova, A.N. (2002). Mir kulturyi (Osnovyi kulturologii) [World of Culture: Basics of Cultural Studies]. Moscow: Izdatelstvo Fyodora Konyuhova [in Russian].

Dobrohotov, A.L., \& Kalinkin, A.T. (2010). Kulturologiya [Cultural Studies]. Moscow: Forum [in Russian].

Frolov, I.T. (2001). Filosofskiy slovar [Philosophical Dictionary]. Moscow: Respublika [in Russian].

Gurevich, P.S. (1996). Kulturologiya [Cultural Studies]. Moscow: Znanie [in Russian].

Its, R.F. (1991). Vvedenie $v$ etnografiyu [Introduction to ethnography]. Leningrad: Izdatelstvo Leningradskogo universiteta [in Russian].

Kagan, M.S. (1996). Filosofiya kulturyi [Philosophy of Culture]. St. Peterburg: Petropolis [in Russian].

Kagan, M.S. (2003). Vvedenie $v$ istoriyu mirovoy kulturyi [Introduction to the history of world culture]. (Pt. 1). St. Peterburg: Petropolis [in Russian].

Karmin, A.S. (2003). Kulturologiya [Cultural Studies]. St. Peterburg: Lan [in Russian].

Kasyanov, B.B. (2010). Kulturologiya [Cultural Studies]. Rostov-on-Don: Feniks [in Russian].

Kiramova, K.A. (2004). Kulturologiya v voprosah i otvetah [Culturology in questions and answers]. Moscow: Velbi [in Russian].

Kostina, A.V. (2010). Kulturologiya [Cultural Studies] (5th ed.). Moscow: KNORUS [in Russian].

Kravchenko, A.I. (2003). Kulturologiya [Cultural Studies] (4th ed.). Moscow: Akademicheskiy Proekt [in Russian].

Kultura i pobut naselennia Ukrainy [Culture and life of the population of Ukraine] (2nd ed.). (1993). Kyiv: Lybid [in Ukrainian]. 
Markaryan, E.S. (1969). Ocherki teorii kulturyi [Essays on the theory of culture]. Erevan: Izdatelstvo AN ASSR [in Russian].

Pigalev, A.I. (1999). Kulturologiya [Cultural Studies]. Volgograd: Izdatelstvo Volgogradskogo gosudarstvennogo universiteta [in Russian]

Podolskaya, E.A., Ivanova, K.A., \& Lihvar, V.D. (2003). Kulturologiya [Cultural Studies]. Harkov: Zolotyie stranitsyi [in Russian].

Ponomarov, A.P. (1996). Etnichnist ta etnichna istoriia Ukrainy [Ethnicity and Ethnic History of Ukraine]. Kyiv: Lybid [in Ukrainian].

Sadohin, A.P. (2006). Etnologiya [Ethnology]. Moscow: Gardariki [in Russian].

Shpengler, O. (1993). Geshtalt $i$ deystvitelnost [Gestalt and reality]. In Zakat Evropyi: Ocherki morfologii mirovoy istorii [The decline of Europe: Essays on the morphology of world history]. (Vol. 1). Moscow: Myisl [in Russian].

Shtompel, L.A. (2001). Materialnaya kultura [Material culture]. In G.V. Drach, \& T.P. Matyash (Eds.). Kulturologiya: Kratkiy terminologicheskiy slovar [Cultural Studies: Concise Dictionary of Terms] (pp. 90-91). Rostov-on-Don: Feniks [in Russian].

Solonin, Yu.N. \& Sokolov, E.G. (Eds.). (2003). Vvedenie v kulturologiyu [Introduction to Cultural Studies]. St. Peterburg [in Russian].

Solonin, Yu.N., \& Kagan, M.S. (Eds.). (2005). Kulturologiya [Cultural Studies]. Moscow: Vyisshee obrazovanie [in Russian].

Stolyanenko, L.D., Samyigin, S.I., Ilyuhina, L.V., \& Larkova, E.P. (2010). Kulturologiya [Cultural Studies] (4th ed.). Rostov-on-Don: Feniks [in Russian].

Taylor, E. (1989). Pervobyitnaya kultura [Primitive culture]. Moscow: Politizdat [in Russian].

Tokarev, S.A. (1970). K metolike etnograficheskogo izucheniya materialnoy kulturyi [To the method of ethnographic study of material culture]. Sovetskaya etnografiya, 4, 317 [in Russian].

Veber, M. (1990). Izbrannyie sochineniya [Selected Works]. Moscow: Nauka [in Russian]. Yartys, A. \& Melnyk, V. (2005). Lektsii z istorii svitovoi ta vitchyznianoi kultury [Lectures on the History of World and Domestic Culture] (2nd ed.). Lviv: Svit [in Ukrainian].

\section{UDC 008:39}

\section{Yuliia Nikishenko,}

PhD in Historical Sciences,

Associate Professor,

National University

"Kyiv-Mohyla Academy",

Kyiv, Ukraine

julianikish@gmail.com

http://orcid.org/0000-0002-8649-93

\section{MATERIAL CULTURE AND ITS INDIVIDUAL COMPONENTS IN THE WORKS OF ETHNOLOGISTS AND CULTURAL STUDIES SCOLARS}

The aim of the article it to show the concept of «material culture» which is perceived somewhat ambiguously, but at the terminological level this concept exists and continues to be widely used by both ethnologists and cultural scientists. Methodology of the 
research consists in the method of analysis and synthesis. We propose to analyze the definitions of the concept of «material culture», which were formulated in ethnology and cultural studies, in order to understand the meaning of the humanitarian sciences.

Key words: material culture, ethnology, culture studies.

\section{УДК 008:39}

\section{Юлия Никишенко,}

кандидат исторических наук, доцент,

Национальный университет

«Киево-Могилянская академия»,

Киев, Украина

julianikish@gmail.com

http://orcid.org/0000-0002-8649-93

\section{МАТЕРИАЛЬНАЯ КУЛЬТУРА И ОТДЕЛЬНЫЕ ЕЁ СОСТАВЛЯЮЩИЕ В ТРУДАХ ЭТНОЛОГОВ И КУЛЬТУРОЛОГОВ}

В последнее время понятие «материальная культура» воспринимается несколько неоднозначно, но на терминологическом уровне это понятие существует и продолжает широко использоваться как этнологами, так и культурологами. Мы предлагаем проанализировать определения понятия «материальная культура», которые были сформулированы в этнологии и культурологии, чтобы разобраться в том, какой смысл вкладывали в него данные гуманитарные науки.

Ключевые слова: вещь, материальная культура, этнология, культурология.

(c) Нікішенко Ю., 2018 